\section{Gardening for change: Community giving gardens and senior food insecurity}

\author{
Kathleen Tims, ${ }^{\text {a }}$ Mark Haggerty, ${ }^{\mathrm{b}} *$ John Jemison, ${ }^{\mathrm{c}}$ \\ Melissa Ladenheim, ${ }^{\mathrm{d}}$ Sarah Mullis, ${ }^{\mathrm{e}}$ and Elizabeth Damon ${ }^{\mathrm{f}}$ \\ University of Maine
}

Special issue:

Food as a Tool for Social Change FALK S Uriveresse

\author{
Submitted January 19, 2021 / Revised March 31, April 17, May 17, June 14, and June 21, 2021 / \\ Accepted June 22, 2021 / Published online September 16, 2021 \\ Citation: Tims, K., Haggerty, M., Jemison, J., Ladenheim, M., Mullis, S., \& Damon, E. (2021). Gardening \\ for change: Community giving gardens and senior food insecurity. Journal of Agriculture, Food Systems, and \\ Community Development, 10(4), 85-101. https:// doi.org/10.5304/jafscd.2021.104.030
}

Copyright (C) 2021 by the Authors. Published by the Lyson Center for Civic Agriculture and Food Systems. Open access under CC-BY license.

\begin{abstract}
An estimated 5.3 million seniors in the United States are currently food insecure (Ziliak \& Gunderson, 2020). Over the next few decades, these senior populations are projected to increase dramatically, which will only exacerbate this issue (Mather \& Kilduff, 2020). Community giving

${ }^{a}$ Kathleen Tims, University of Maine, Honors College; Orono, ME 04469 USA; kathleen.tims@maine.edu

$\mathrm{b} *$ Corresponding author: Mark Haggerty, University of Maine, Honors College; Estabrooke Hall; Orono, ME 04469 USA; +1-207-944-3816; haggerty@maine.edu

c John Jemison, Extension Professor of Soil and Water Quality, University of Maine; 495 College Avenue; Orono, ME 04473 USA; jemison@maine.edu

d Melissa Ladenheim, University of Maine, Honors College; 5727 Estabrooke Hall; Orono, ME 04469 USA; melissa.ladenheim@maine.edu

e Sarah Mullis, University of Maine, Honors College; Orono, ME 04469 USA; Semullis00012@gamil.com

${ }_{\mathrm{f}}^{\mathrm{f}}$ Elizabeth Damon, University of Maine; Orono, ME 04469 USA; elizabethdamon8493@gmail.com
\end{abstract}

gardens are an emerging strategy to increase food access and offer a solution to fight food insecurity locally (Chicago Community Gardeners Association, 2014; Furness \& Gallaher 2018; Sutphen, 2018). This research seeks to answer questions related to rural, senior food insecurity through a case study of a long-term community giving garden project in Orono, Maine. Based on survey data and personal interviews, this study analyzes senior participation in the Orono Community Garden (OCG) program, the impact on participants' food security status, and senior participants' perceptions of the experience. The results indicate that the OCG program functioned to increase food access by providing fresh food deliveries directly to senior households in need, alongside a constellation of

\section{Funding Disclosure}

We would like to thank the following funders from the University of Maine for their support of this project: Center for Undergraduate Research, Charlie Slavin Funds, Dick Hill Funds, and the Sustainable Food System Research Collaborative. 
local food assistance programs located in Orono. Participants also viewed the OCG program as a source of destigmatized and socially acceptable food access, in contrast to other food assistance programs. Community giving gardens, like the OCG program, can be an effective tool to combat senior food insecurity by providing nutritionally adequate, destigmatized food access while building local food economies.

\section{Keywords}

Alternative Food Systems, Community Garden, Food Access, Local Agriculture, Senior Food Insecurity, Stigma, Social Change

\section{Introduction and Literature Review}

Food insecurity is pervasive throughout the United States. In 2018, 11.1\% of Americans, or 37 million people, were considered to be food insecure (Coleman-Jensen, 2019; Feeding America, 2020a), defined as having limited or intermittent availability of nutritionally adequate and safe food accessible in socially acceptable ways (U.S. Department of Agriculture Economic Research Service [USDA ERS], 2019). Many food-insecure individuals utilize public food assistance programs and accept private food donations from food pantries and soup kitchens. However, these private aid agencies struggle to meet the needs of vulnerable, foodinsecure populations.

Community gardens can provide significant food relief during times of economic struggle and help alleviate food insecurity (Kurtz, 2001). Giving gardens, such as the Orono Community Garden (OCG) program, are donation-model community gardens where fresh produce is grown, harvested, and delivered directly to the recipients who in this case are not actively engaged in growing the food themselves (Chicago Community Gardeners Association, 2014; Furness \& Gallaher, 2018; Sutphen, 2018). Producing food to be given to people in need, community giving gardens offer a possible solution in fighting food insecurity, yet the impact of gardens on senior food insecurity is not fully understood. This research aims to explore the community garden model and rural, senior food insecurity through a case study of a long-term (15year) community giving garden project in Orono,
Maine, where food grown and harvested by volunteers is then donated to seniors living nearby. In addition, we look at the barriers to participation in food assistance programs and seniors' selfperception of their own food insecurity.

\section{Senior Food Insecurity and Barriers to Participation in Food Assistance}

The number of seniors (people aged 60 and over) in the United States is projected to more than double by 2060 , then composing almost a quarter of the total population (Mather \& Kilduff, 2020; Vespa et al., 2020). An estimated 5.3 million of today's seniors are food-insecure, a number that is only likely to increase as the senior population grows (Dooley, 2017; Ziliak \& Gunderson, 2020). Older Americans are a particularly vulnerable population, often challenged with financial and health-related issues that are compounded by food insecurity (Dooley, 2017).

Several federal programs provide assistance, grants, food, and cash relief to low-income families, but only a few cater specifically to senior citizens, and these do not necessarily meet their needs (Dabrowska, 2017; Ratcliffe \& McKernan, 2010). The USDA provides benefits to all vulnerable populations through programs such as the Supplemental Nutrition Assistance Program (SNAP) and the Emergency Fund Assistance Program (Dabrowska, 2017). The Older American Act, instituted 50 years ago by the U.S. Department of Health and Human Services, provides meals to seniors through the Congregate Nutrition Program and the Home Delivered Nutrition Program and also partially funds services such as Meals on Wheels (Meals on Wheels America, 2019). Another senior-focused supplemental program provided by the USDA is the Commodity Supplemental Food Program (CSFP), which distributes monthly food packages to low-income elderly (USDA, 2019). Although these programs help meet the needs of many food-insecure seniors, they are unable to keep up with the growing demand for food assistance (Rinehart et al., 2016).

In addition to the public food assistance programs noted above, there are private food assistance programs such as food pantries, food banks, and soup kitchens. Both public and private assis- 
tance programs have barriers to seniors' participation. A study by Dean, Sharkey, and Johnson (2011) found that seniors display low levels of participation in nutrition assistance programs because they do not know what public and private programs are available to them in their communities. Further difficulty in accessing food assistance programs can be attributed to social isolation among older populations (Cotterell et al., 2018) and other consequences of limited social capital, such as increased nutritional risks and lack of emotional support (Dean et al., 2011; Zepeda, 2017). Other studies attributed the lack of senior participation to a variety of factors including misconceptions regarding the available programs, eligibility restrictions, and technological difficulties in the application process (National Council on Aging, 2019; Rinehart et al., 2016). Beyond barriers of awareness and access, overcoming food insecurity for seniors also involves seniors acknowledging their food insecurity and overcoming the negative social stigma associated with assistance programs. Societal shame and feelings of embarrassment have been found to be motivating factors for seniors in hiding hunger and avoiding assistance (Wolfe et al., 1996; Zepeda, 2017). These barriers have resulted in SNAP-eligible seniors demonstrating the lowest participation rates of any demographic group (Gualtieri \& Donley, 2016), with only two out of every five qualifying seniors participating in SNAP benefits (National Council on Aging, 2019; Rinehart et al., 2016). At present, $83 \%$ of lowincome (incomes below $185 \%$ of the poverty threshold), food-insecure seniors are not receiving food assistance to enable them to meet their nutritional needs (Martin et al., 2003; Meals on Wheels America, 2019).

\section{Community Gardening as a Potential Strategy to Address Barriers}

This project aims to help remedy food insecurity through the Orono Community Garden, an initiative where community members collaborate to serve the senior low-income population. Community gardens, such as the OCG, are shared spaces where organized and often collaborative agricultural projects produce and provide access to fresh fruits and vegetables (D'Abundo \& Carden, 2008;
Drake \& Lawson, 2015; Gerster-Bentaya, 2013). Additionally, these garden projects have been found to promote the formation of social ties, build community capacity, create attractive public spaces, and improve public health and wellbeing by producing healthy food (Obach \& Tobin, 2014; Teig et al., 2009; Twiss et al., 2003). Historically, community garden projects have been created as a way to supplement food supplies and maximize benefits to individuals, communities, and the environment (Carney et al., 2012; Kurtz, 2001; Okvat \& Zautra, 2011; Pudup, 2008). Community gardens can be seen as a form of civic agriculture, establishing centers of "public pedagogy" (Walter, 2013), addressing issues of food injustice and social disparity (Dwiartama \& Piatti, 2016; Irazábal \& Punja, 2009), increasing engagement in local systems, and creating civic pride (Obach \& Tobin, 2014). When the focus of the garden becomes one where the food is grown to educate gardeners and donate the food produced to specific groups, gardens become sources of social capital and exchange (Drake \& Lawson, 2015) and can function to create "collective wellness" in their local populations (D'Abundo $\&$ Carden, 2008). Consequently, community gardens have been a critical tool in creating food access and contributing to the food security of vulnerable populations (Carney et al., 2012; Twiss et al., 2003).

\section{Maine in Context: Orono and the Orono Community Garden Project}

With the highest percentage of seniors in the U.S., Maine is a particularly relevant location for studying senior food insecurity (U.S. Census Bureau, 2010). Much of the state's rural population struggles with poverty, and almost a third of Maine seniors are identified as low-income (Schaefer \& Mattingly, 2016). Maine has the highest rate of food insecurity in New England (Good Shepherd Food Bank \& Preble Street, 2017), but it also has a vibrant local food movement, including community gardens, which could be utilized to mitigate food insecurity (Burnett \& Matlins, 2006; Feulner, 2015; Good Shepherd Food Bank \& Preble Street, 2017; Pingree, 2012). This backdrop provides the context in which the Orono Community Garden was created and has thrived. 
Stemming from a public educational program through the University of Maine Cooperative Extension, the OCG was started in the village of Orono in 2004. Since it began, the OCG and its volunteers have grown and delivered fresh produce to residents of two adjacent, low-income senior housing complexes in Orono in partnership with local stakeholders, including the Orono Parks and Recreation Department and the University of Maine Cooperative Extension horticulture program. Local farmers associated with the Orono Farmers Market also contribute unsold produce to the garden's deliveries. The OCG is categorized as a giving garden because all its produce is given away to these seniors, who often visit the garden but play no measurable role in growing or harvesting the produce. Each year, 20 to 30 volunteers work in the OCG, including the garden director, university students, master gardeners in training, and town members. In a typical week during the growing season, the OCG requires four to eight volunteers contributing approximately 22 hours of total work. The OCG director is responsible for approximately eight hours per week. Material costs for the garden (seeds, compost, tools, etc.) are estimated to be US $\$ 1,000$ annually. Seniors living in the nearby housing units are visited by volunteers who go door to door asking if they are interested in receiving produce grown in the garden. On average, about 50 out of a total of 70 households participate each year to receive a weekly delivery of freshly harvested vegetables.

The OCG has three main goals: (1) teach volunteers intensive organic gardening methods, (2) help alleviate senior food insecurity, and (3) reduce senior isolation through the interactions between the volunteers and recipients when the produce is delivered. As the OCG provides high-quality produce to these low-income seniors and creates opportunities for social interaction between participating seniors and the volunteer community, there are many potential benefits for its local households that address nutritional and social needs by this population (Damon, 2017; Mullis, 2016).

The OCG volunteers are taught intensive organic gardening methods, producing 20 different annual vegetable varieties on 52 raised beds ranging in size from $4 \times 4 \mathrm{ft} .(1.2 \times 1.2 \mathrm{~m})$ to $4 \times 30 \mathrm{ft} .(1.2 \mathrm{x} 9.1$ $\mathrm{m})$, providing approximately $2,300 \mathrm{ft}^{2}\left(214 \mathrm{~m}^{2}\right)$ of production area. Most beds are double cropped in the season when possible. In addition, a wide range of annual vegetables are also produced on a 5,000 $\mathrm{ft}^{2}{ }^{2}\left(465 \mathrm{~m}^{2}\right)$ plot at the University of Maine Rogers Farm, located several miles from the OCG. Further supplementing the produce grown in the OCG are extra vegetables grown for research projects at the University of Maine, as well as gleaning from the Orono Farmers Market, where farmers regularly contribute 10 to $15 \mathrm{lbs}$. (4.5 to $6.8 \mathrm{~kg}$ ) of leafy greens and other perishable vegetables at the end of their market day. Each week, vegetables are harvested, cleaned, and bagged for delivery. For the last 15 years, from late June through late September, the OCG project staff and volunteers have delivered an average of $7 \mathrm{lbs}$. (2.7 to $3.6 \mathrm{~kg}$ ) of produce each week to approximately 50 senior recipients (Haggerty et al., 2016).

As we are seeking ways to understand where the OCG program fits into a larger strategy of addressing senior food insecurity in rural areas like Maine, we discovered that few studies have been conducted to date that examine the impact of community giving garden programs on food insecurity (Carney et al., 2012; Committee on National Statistics, Division of Behavioral and Social Sciences and Education, Food and Nutrition Board, Nation Research Council, \& Institute of Medicine, 2013; Macias, 2008). Likewise, we found limited research focusing on senior perceptions of food insecurity relief programs and their associated social stigmas, issues that emerged from our interviews with the recipients of the food (Damon, 2017; Mullis, 2016; Okvat \& Zautra, 2011; Wolfe et al., 1996), as well as a paucity of information on the impact of local activities that attempt to alleviate food insecurity (Dean et al., 2011). Thus, this assessment of the OCG program team takes up these questions and looks to address these knowledge gaps regarding seniors' barriers to participation in food assistance programs and the community giving garden model. Specifically, we examine the potential of community giving gardens to increase access to healthy food, seniors' perceptions of their own food insecurity, and the stigmas associated with food assistance programs. 


\section{Methods}

The study used a mixed-methods approach that included a survey and two series of interviews. All interviewees were residents of two low-income housing projects in Orono, Maine. A fourquestion, open-ended survey with a self-addressed stamped envelope for its return was included in the final delivery bags of the fall 2015 harvest to the 55 OCG food recipients, and 18 surveys were returned. The survey questions focused on the length of participation in the OCG, the impact of the garden vegetables on the participants' diet, the perceived impact on the participant of ending the giving garden, and the participants' perception of their relationships with the garden volunteers (Mullis, 2016).

Two sets of semistructured interviews lasting 30 to 60 minutes were conducted during the harvest seasons of 2015 and $2017 .^{1}$ Two interviewers, neither of whom was affiliated with the OCG, were trained and conducted the interviews. One interviewer conducted all of the 2015 interviews and a second interviewer conducted the 2017 interviews. Both sets of interviewees were selfselected. On the last day of the fall 2015 garden deliveries, an individual researcher and the garden manager asked seniors, at their home, if they were willing to participate in interviews. Twenty-five seniors provided contact information to set up an interview, and ultimately 12 participants were interviewed. One interview was omitted due to inconsistencies in the responses. The open-ended questions focused on the seniors' motivation for being involved with the community garden; personal experience and perceptions of food access and food insecurity; food habits such as cooking ability, seasonal food storage, and reliance on food sales; and current participation in food assistance programs. Several additional questions examined senior isolation and the participants' perceptions of the garden's role in creating social capital (Mullis, 2016).

The second set of interviews was conducted during fall 2017 with residents who had either never participated in the garden or chose not to continue their participation in the OCG that year.
Initial contact with potential interviewees was facilitated through a monthly newsletter generated by the management organization of the senior complexes. This contact was followed up by a researcher knocking on residents' doors and asking to schedule interviews. Ten interviews were conducted; four were residents who had never participated in the OCG, while the remaining six had previously participated. The open-ended questions were the same as those asked in the first set of interviews, along with questions focusing on why these interviewees chose not to participate in the OCG that season.

All interviews were conducted and recorded in the seniors' homes and then transcribed. Twentytwo of the 70 households in the two senior housing complexes participated in the interviews, although one response was omitted as mentioned above. Following transcription, interviews were analyzed and manually coded using an iterative process where themes and codes emerged through this process reflecting the research questions and relevant literature (Mullis, 2016; Saldaña, 2013).

\section{Results}

Based on survey data and personal interviews, this case study analyzed the decisions of 21 seniors to participate in the OCG program and their perceptions of the experience. Our work examined what the OCG program can provide to food-insecure seniors and how it played a role in the foodsecurity status of the participants. We also explored the factors that influenced participation in food assistance programs and seniors' self-perceived level of food security. The knowledge gained from this study will better inform how we build socially just and resilient food systems and invest in ways to provide adequate food access to vulnerable groups.

\section{The Orono Community Garden Program}

In our interviews with seniors participating in the OCG program, we found that many reported being food secure and relying on a network of food assistance programs, including the OCG program. Of the 11 interviews, $55 \%$ of senior households

${ }^{1}$ Interview questions are available from the corresponding author upon request. 
shared that they always looked forward to the fresh food from the OCG (Table 1). A typical quote describing this feeling included, "I like everything about it [the deliveries]. It's just marvelous, I run to the house and dust 'em off, wash 'em off, put them in bags if I'm going to save them" (Interview 6, Fall 2015), or, "because it's kind of like a surprise" (Interview 5, Fall 2015), and more often, "we're just grateful to get it. We love the fresh vegetables" (Interview 6, Fall 2015). Eighty-two percent of seniors participating in the OCG confirmed that food deliveries from the garden substituted or replaced food they would normally need to buy. One senior alluded to receiving the additional food from the garden enabling them to be able to have vegetables that, "most of the time, I just can't afford is certainly a treat" (Survey "Selected Evals," page 9 of 9). Nine out of the eleven participating seniors indicated in their interviews that the supplemental fresh produce contributed a benefit to their normal diets and gave them additional options in budgeting for food and other expenses. Sixty-three percent of seniors reported consuming more vegetables than they would normally while the garden was in season because purchasing them in the store was too expensive (Mullis, 2016). One participant noted, "I don't feel like I could afford it [fresh vegetables]" (Interview 10, Fall 2015), and "I just think it [the garden] allows me to buy some of the extra things that I normally couldn't" (Interview 10, Fall 2015). Responses such as these were typical in our interviews and confirmed the crucial ways the OCG program augmented the food options of many of the seniors it serves and enabled them to better use their fixed income to meet their needs.

Even with free, nutritious produce being delivered directly to their homes, some seniors chose not to participate, and our study sought to under-
Table 1. Senior Participants Perceptions of Food Insecurity and Impact of the OCG Program (n=11)

\begin{tabular}{lc}
\hline Interviewees' reason for valuing the OCG program & Number a \\
\hline Self-report as currently food secure & 11 \\
\hline Cited past food insecurity & 6 \\
\hline Reported looking forward to fresh food & 6 \\
\hline Reported pressure to not waste food & 4 \\
\hline Cited preservation of garden food & 7 \\
\hline Reported thriftiness with food money & 5 \\
\hline $\begin{array}{l}\text { Reported that garden deliveries added to amount of food } \\
\text { they were able to access }\end{array}$ & 3 \\
\hline $\begin{array}{l}\text { Reported that garden deliveries substituted for food they } \\
\text { would typically acquire }\end{array}$ & 8 \\
\hline
\end{tabular}

Interviewees could provide more than one reason.

Table 2. Senior Nonparticipants' Reasons for Terminating Deliveries $(n=10)$

\begin{tabular}{lc}
\hline Reason & Number ${ }^{\text {a }}$ \\
\hline Self-report as currently food secure & 10 \\
\hline Cited past food insecurity & 4 \\
\hline Reported pressure to not waste food & 2 \\
\hline Reported disliking type of food received & 2 \\
\hline Reported disliking quantity of food received & 3 \\
\hline Reported having trouble eating certain food & 2 \\
\hline Reported that food from the garden was dirty & 3 \\
\hline Reported ease with getting to grocery store & 6
\end{tabular}

Interviewees could provide more than one reason.

stand why. In our second set of interviews, 10 seniors were asked to explain their decisions for opting out of the program (Table 2). Health limitations drove nine of the 10 seniors' choice to opt out, citing medications that restricted their diet or physical constraints that made preparing and cooking the produce too difficult (Interview 3, 4, 5, 6, Fall 2015; Interview 12, 13, 15, 18, Fall 2017). Others who opted out of the OCG program explained that they "couldn't take care of what we had, and you don't want to waste it, because there's too many people out there that need it" (Interview 18, Fall 2017). Likewise, former participants acknowledged how much they had enjoyed the fresh food deliveries, but worried that others were 
in greater need, and they did not want to waste food resources. Six of the ten nonparticipating seniors did report having enjoyed their deliveries from the OCG in the past, but said that they felt their food access was more secure compared to others. One household explained that their main reason for stopping was because they "knew the gardens weren't that big. They couldn't cover that many people, so somebody else could use it more than we could" (Interview 16, Fall 2017). Although this household chose not to participate, they did admit to missing the food deliveries and visits from volunteers, and shared that "we know you're around during the week because we see you coming and going. I think it's wonderful" (Interview 16, Fall 2017). All 10 seniors who had opted out of participating in garden deliveries, for one reason or another, were also currently participating in at least one other food assistance program and all indicated knowing of other sources of food assistance available to them. Despite appreciation for the OCG program, the seniors' choice not to participate was motivated by one of several factors: health constraints, the desire not to waste food, or the belief that someone else could better utilize the free food deliveries. Both interview sets verified the ways the OCG program reduces the stress of food budgeting, although the level of stress varied from person to person. Food deliveries from the OCG program supplemented seniors' diets with healthier and otherwise unaffordable options. These insights reinforce the many benefits of a giving garden, yet still leave us to question the potential for community giving garden projects to significantly increase food access and improve food security.

\section{Constellation of Programs}

In Maine, almost $57 \%$ of adults age 65 and over lack the financial resources required to cover their basic needs, including their food (Dooley, 2017). A network of supplemental food programs has been developed to improve food security. For example, in Orono, support for seniors can be found through a variety of home-delivery food program services including those run by local volunteer organizations, such as the OCG, the Parker Dining Room, and Eastern Area Agency on Aging-Meals on Wheels (Bangor Daily News Staff, 2011; Eastern
Agency Area on Aging, 2018). Public food assistance includes programs such as SNAP benefits and the Maine Senior FarmShare Program. FarmShare is a federally funded food assistance program that can provide US $\$ 50$ worth of fresh, local produce to eligible seniors who apply each year, but this program operates on a first-come, first-served basis and only during the growing season (Maine Department of Agriculture, Conservation and Forestry, n.d.). Parker Dining Room is a private project operating with the help of one of the local low-income housing facilities. Funded by the Eastern Area Agency on Aging and staffed by volunteers, it provides both a site where local seniors can gather to share low-cost meals and also arranges home delivery for immobile residents. Foodinsecure seniors may also utilize food pantries and other locally operated, private food relief networks throughout the state (Good Shepherd Food Bank \& Preble Street, 2017; Graham, 2014). This constellation of food assistance programs decreases the food insecurity of seniors by increasing their access to safe and nutritionally adequate foods.

We found the majority of the interviewed seniors utilized a combination of public and private assistance programs. While senior households often use both types of assistance, the interrelationship of private and public food assistance programs is understudied, and the nature of senior participation is influenced by numerous factors. In estimating senior participation rates, studies done by Daponte (2000) and Martin et al. (2003) found that elderly, low-income households were more likely to utilize only public assistance $(15 \%-34 \%$ of seniors), compared to using only private assistance (21\%-26\% of seniors), or combining both public and private forms of food assistance $(8 \%-9 \%$ of seniors). These studies also found that $36 \%$ to $55 \%$ of seniors were not participating in any form of food assistance (Daponte, 2000; Martin et al., 2003). Our results found $29 \%$ of seniors interviewed to be using only public sources of food assistance, $19 \%$ of seniors using only private forms of food assistance, and $52 \%$ of seniors using both public and private food assistance programs (Table 3). No senior in our study chose to not use food assistance. Participation in only public or only private forms of food assistance was consistent 
Table 3. Overall Participation Rates in Each Type of Program $(n=21)$

\begin{tabular}{|c|c|c|c|c|}
\hline \multirow{2}{*}{$\begin{array}{l}\text { Number of Assistance Programs } \\
\text { Participating In }\end{array}$} & \multirow[b]{2}{*}{ Only Public } & \multicolumn{3}{|c|}{ Both Public and } \\
\hline & & Only Private & Private & Total in Each Program \\
\hline 0 programs & $0 \%$ & $0 \%$ & $0 \%$ & $0 \%$ \\
\hline 1 program & $14 \%$ & $19 \%$ & $0 \%$ & $33 \%$ \\
\hline 2 programs & $14 \%$ & $0 \%$ & $29 \%$ & $43 \%$ \\
\hline 3 programs & $0 \%$ & $0 \%$ & $19 \%$ & $19 \%$ \\
\hline $4+$ programs & $0 \%$ & $0 \%$ & $5 \%$ & $5 \%$ \\
\hline Total \% that participated & $29 \%$ & $19 \%$ & $52 \%$ & $100 \%$ \\
\hline
\end{tabular}

with the estimated rates of typical senior households in the U.S. (Daponte, 2000; Martin et al., 2003); however, the participation rate of seniors who used both public and private food assistance was much higher than the observed national participation rates (Table 3). Our interviews also concluded that all 21 seniors were utilizing at least one food assistance program, with a majority participating in multiple food assistance programs.

The programs with the highest levels of participation included the OCG, the Maine Senior FarmShare Program, and SNAP. Eighty-one percent of the seniors participated in public assistance programs, combining or choosing either SNAP "food stamps" or the Maine Senior FarmShare. This outcome is also consistent with studies indicating that those in need predominantly rely on public rather than private sources of food aid (Wu \& Eamon, 2007). Our observed participation rate in SNAP benefits (52\%) was only slightly higher than the most recently reported national average rate $(48 \%)$ of SNAP benefit participation rate by seniors (USDA ERS, 2019). No seniors, however, reported using public assistance through the Meals on Wheels home-delivery service. Multiple seniors also expressed their distaste for the Meals on Wheels service; one even cited that "it doesn't work," and that she'd rather go hungry than pay for "a peanut butter sandwich on stale bread and a can of soup" (Interview 12, Fall 2017). None of the seniors interviewed in this study utilized local food banks or food pantries. Interviewees shared that they did not feel the food was adequate. Seniors noted that the local food banks did not meet their expectations; however, this does not necessarily reflect on food banks in other areas. Typical responses to questions about past food bank or food pantry use included descriptions such as, "the food pantry ... they had food that wasn't the healthiest, like bread and starchy stuff; so, I don't know that I ate as healthy as I could've" (Interview 10, Fall 2015), discomfort with the facility as in "the inside just isn't, doesn't look like it's clean enough to be a food bank" (Interview 21, Fall 2017), or that, even in desperate times, they felt too embarrassed to use the food pantries (Interview 12, Fall 2017). In contrast, seniors were much more positive regarding their experiences with both the OCG and Parker Dining Room, the private food assistance programs mentioned previously, both of which provide consistent food access and reliable support for those who choose to participate. Positive experiences regarding the OCG program included statements such as, "but I like the Orono garden, you know, to get the fresh vegetables ... and stuff, it's really good. I look forward to that every year" (Interview 2, Fall 2015). They also shared that they enjoyed the visits from volunteers just as much as they enjoyed the free food: "Well it's a little bit of both. The volunteers bring the food ... all that makes a big difference. I enjoy the food, but I like the talk, so it's something to look forward to" (Interview 14, Fall 2017). These local organizations were often described with gratitude and compliments, recognizing the nutritious food and its addition to their diet.

\section{Food Insecurity}

In examining the food insecurity of seniors, it is important to not only understand the nutritional 
needs of seniors' diets and how seniors are accessing food, but also their perception of their own relative food security status (Gualtieri \& Donley, 2016; Quandt et al., 2001). All seniors indicated that they were currently food secure when directly asked during their interviews. However, the reality of their food-security status was frequently contradicted with other comments made during the interviews, revealing anxieties about food access and budgets, thriftiness when food shopping, disrupted eating patterns, and sacrifices required for availability of adequate food. One of the seniors shared that they did not feel insecure as long as they had "the basics. You know, I can usually whip up something or get by. ... I don't make a meal" (Interview 14, Fall 2017). Others reported that they navigate shopping only on senior discount days or only purchasing food that is on sale (Interview 1, 6, Fall 2015; Interview 12, 17, 21, Fall 2017), that they only buy fresh produce in the summer months when it is less expensive (Interview 12, 17, Fall 2017), that they "save a lot [of fresh produce from the OCG] for winter" (Interview 7, 12, Fall 2017), and that the amount of food they have "runs low" each month before their next round of SNAP benefits come in (Interview 2, 10, Fall 2015; Interview 14, 15, 19, Fall 2017) Some seniors reported their reliance on food stamps: "by the end of the month I'm just right so that I'm low, low, and then my check comes ... by the end of that month going into the next, I'm ready for the food stamps. I just never go hungry," even going on to confirm that it can sometimes get to the point where the interviewee "really needed those stamps" (Interview 15, Fall 2017). One interviewee indicated that when they run low or out of food, they "drink a lot of water" to cope (Interview 19, Fall 2017).

Stresses about food and thrifty food habits were characteristics present in many interviews and were used as indicators to identify the level of food security of these seniors.

The USDA Economic Research Service defines food security in four categories: high food security (HFS), marginal (MFS), low (LFS), and very low (VLFS) (USDA ERS, 2019). High food security is defined as having a nutritious diet and consistent, safe food access. Marginal food security is defined as households that report having problems at times, or anxiety about, accessing adequate food to meet their nutritional needs (USDA ERS, 2019). The $4.3 \%$ of American households that experience low food security are characterized by being, at times, unable to acquire a variety of adequate food for household members due to insufficient money and other resources (ColemanJensen et al., 2019). Those defined as having very low food security experience disrupted eating patterns and reduced food intakes, at least sometimes during the year, because they can not afford sufficient food (Coleman-Jensen et al., 2019). An analysis of the 21 interviews for language and themes related to the interviewees' food access experience during the prior year were used to estimate their level of food security, as defined by the USDA. The interviews were coded to determine seniors' ability to access food, typical eating patterns, personal definition of food insecurity, perception and coping strategies with food shortage, experiences of past food insecurity, and use of food assistance. Individuals' codes were then compared to USDA food security category definitions in order to estimate their food security status at the time of the interview. This assessment yielded contrasting results to their level of self-reported food security. More than half the seniors interviewed noted anxiety about food access and almost a third of all seniors were found to fit the definition of having very low food security (Table 4).

Table 4. Estimated Level of Food Security of Seniors Interviewed $(n=21)$

\begin{tabular}{lccc}
\hline Food Security & Percent Reporting & Participants in OCG Program & Nonparticipants in OCG \\
\hline High Food Security & $38 \%$ & 4 & 4 \\
\hline Marginal Food Security & $14 \%$ & 2 & 1 \\
\hline Low Food Security & $19 \%$ & 2 & 2 \\
\hline Very Low Food Security & $29 \%$ & 3 & 3 \\
\hline
\end{tabular}


Almost all these seniors struggled to express their inadequate access to food in terms of insecurity and, when prompted by the interviewer, explained that they were currently food secure. Feeling like they have enough food to get by, often many seniors do not accurately define their level of food insecurity (Graham, 2014; Quandt et al., 2001). Seniors may misreport their food insecurity because they felt they had inherited a learned "resilience" and knew how to shop intelligently, make do, and stretch their resources, despite having constraints on income, personal mobility, or access to transportation (Frongillo \& Warren, 2018; Quandt et al., 2001). When asked if they were struggling with insufficient food resources, all but one of the seniors interviewed responded as feeling confident in their security. However, all 21 seniors interviewed also reported that they relied on various assistance programs or altered their eating patterns due to a lack of resources. After agreeing that they were not worried about their access to food at the moment, some interviewees gave conflicting responses such as, "I [ran] low this month, but food stamps come in tomorrow" (Interview 13, Fall 2017), or statements such as, "I've got plenty of food right now. Mostly canned stuff, but I wait'll it's on sale and then I kinda get, you know, extra" (Interview 1, Fall 2015). Another senior shared that they never had difficulty accessing fresh food, but later reported that, "we get through [say] June to September. That's fine, but after that no" (Interview 7, Fall 2015). Being food secure includes not feeling anxious about food sufficiency or lack of food and not reducing one's food intake or the quality and variety of diet. Seniors may feel like they have enough and may have "never experienced a time where they didn't have enough food to eat" (Interview 15, Fall 2017), but still experience food insecurity, as indicated by interview statements such as, "it's always nice to have a little extra [food]," (Interview 15, Fall 2015) or agreeing that each month it can get hard toward the end of the month. In both sets of interviews, seniors were vocal about their food thriftiness or shared stories of past challenges to put food on the table, but declined to identify themselves as having worries about the amount of food they had or ever having experienced food insecurity. Those inter- viewees who had experienced past food insecurity shared that those episodes felt "embarrassing" (Interview 8, Fall 2015), and unpleasant enough that they "didn't want to burden" (Interview 10, Fall 2015) or ask for help from others, even family members. Consistent with these findings, admitting insecurity is challenging, and the real number of food-insecure seniors is likely higher than what is self-reported.

\section{Discussion}

These results demonstrate the need for the OCG program. National statistics and interviewees' comments support the need for such a program. The free weekly deliveries of fresh food supplemented and supported the diets of the seniors interviewed. The garden was consistently recognized as a convenient source of food; deliveries to their doorstep relieved significant food access issues, such as transportation or physical limitations (Martin et al, 2003; Rinehart et al, 2016). The free deliveries from the OCG were also noted to reduce anxiety about food budgets or food sufficiency. When asked if the amount of money that was spent on groceries changed at all when receiving food from the garden, interviewees responded with statements such as "It's, money, I don't buy the vegetables and that sorta thing" (Interview 2, Fall 2015), or, "Oh yes. I love fresh vegetables, and sometimes my neighbors feel like they got too much and will give me some of theirs. So, it really affects what I eat. ... I just think it allows me to buy some of the extra things that I normally couldn't" (Interview 10, Fall 2015), and "I spend a lot less.... 'Cause you get the food from the garden, and you stretch what you get. I mean, lots of times I can take what I have and maybe two or three meals go in the freezer.... Big saving when we can get it from the garden" (Interview 7, Fall 2015). Our interviews found that the garden provided additional access to nutritious food for these seniors, many of whom cobble together different avenues of food assistance to meet their needs.

All of these seniors were utilizing at least one food assistance program, and a majority of the seniors reported participating in multiple local food assistance programs. Both the high overall partici- 
pation rate and high combined participation rate, in public and private assistance programs, were inconsistent with the observed national rates of senior participation in food assistance programs. Unlike the national findings, all of the Orono respondents were participating in at least one food assistance program. This could be attributed to the multiplicity of programs available in the community and the support provided to seniors to access these existing programs. The OCG actively recruits seniors into its delivery routines and has effectively maximized the number of recipients to whom the garden can provide food. This approach eliminates any eligibility barriers that are sometimes presented with other food assistance programs, such as qualification standards or complicated enrollment paperwork, and increases its accessibility. The OCG program also functioned as a food delivery service and not a pick-up program, providing increased access to seniors who may have been challenged by transportation or mobility barriers. These lowincome senior housing complexes also had a champion resident service coordinator who facilitated their participation in public and private programs and ensured that households were provided with opportunities to access food. A majority of interviewees were either current or past participants in the OCG, influencing the likelihood that participants would be willing to engage in some form of supplemental food assistance.

Our results indicated that the interviewed seniors are using a combination of public and private programs at a much higher rate than observed in national trends, with $52 \%$ of the seniors interviewed using both types of assistance programs and all seniors participating in some type of food assistance. The majority of seniors who utilized SNAP benefits also participated in other existing programs including food aid from private sources such as the OCG and Parker Dining Room or additional deliveries from the federally funded Maine FarmShare program.

With a high percentage of eligible seniors declining to engage in food security programs, we sought to identify the potential barriers. Low senior participation in public food assistance programs is often attributed to difficulties with the application process and stigma associated with SNAP as a "welfare" program (Frongillo \& Horan, 2004; Meals on Wheels America, 2017; Rinehart et al., 2016; Wolfe et al., 1996). In the most recent studies regarding senior perception of SNAP, Gabor, Williams, Bellamy, Hardison, and Dagata (2002) found that stigma was the most common reason for not applying for SNAP benefits. The existence of stigma and "negative self-characterizations" from participation in welfare is a well-documented issue (Moffitt, 1983), and may be an underlying element to explain how the elderly view their food security. Many seniors find it very difficult to ask for help after having supported themselves for so many years. Having been enculturated with values generated by the Great Depression and a World War, seniors may reflect with pride on their abilities to withstand hardship and effectively make compromises to survive (Quandt et al., 2001). In contrast to the government's definition of food insecurity, seniors' perception is influenced by their past and their instilled values of self-sufficiency, as demonstrated in these interviews. These perceptions hinder many seniors' ability to acknowledge their food insecurity and recognize their own need for assistance. Consistent with these findings, admitting insecurity is challenging, and the real number of food-insecure seniors is likely higher than what is self-reported.

Similar sentiments can be further associated with private food assistance programs. Utilizing food pantries or borrowing money for food can seem socially unacceptable avenues for food procurement, and often lead to shame and hurt pride (Wolfe et al., 2003). In our interviews, some seniors shared negative attitudes toward food pantries, citing them to be dirty (Interview 21, Fall 2017) or having inadequate and unhealthy food options (Interview 10, Fall 2015). Negative associations were shared by interviewed seniors about many of the available programs, yet participation in both types of public and private programs was prevalent. Furthermore, no interviewed senior reported participating in local food banks or pantries, reinforcing the literature that suggests that many seniors have negative perceptions about using private food assistance programs. Although participation rates for public programs were higher in our study, it is unclear whether the seniors actually preferred 
public forms of assistance over private programs. What these households consider to be viable, socially acceptable resources can be more complex than public versus private assistance, as it was common for many of these households to attribute negative associations or feelings of shame to participating in any source of assistance.

Seniors participating in the OCG did not report feeling uncomfortable or feeling judged when receiving food from the garden, a stigma that is often attributable to other forms of food assistance (Frongillo \& Horan, 2004; Martin et al., 2003; Rinehart et al., 2016; Wolfe et al., 1996). Justifications for nonparticipation in the OCG program were based on health limitations, inability to consume leafy greens due to medications, concerns about wasting garden vegetables, or issues with the physical capacity to cook. For example, an interviewee who had stopped participating in garden deliveries noted, "well, the food that you gave me, I couldn't eat it all, and it would go bad; I'd have to throw it away. So I decided to stop.... I liked it. ... Yours is good, fresh stuff when I get it. But there's just too much" (Interview 21, Fall 2017). Participants never cited feelings of shame in receiving the food donations from the OCG, instead noting how much they enjoyed the "lovely" deliveries, how much they looked forward to the drop-offs (Interview 1, 2, 3, 4, 8, Fall 2015; Interview 13, 14, 15, 18, Fall 2017), and "what a nice service it [the OCG] is" (Interview 18, Fall 2017). The food delivery approach was noted to be destigmatizing and increased the ability of many seniors to participate. When asked if the deliveries were valuable, one senior responded, "I mean, I could walk down there-I could, but I cannot. I've got a sore body. Can't wait to get rid of it. I don't know if I ever will. Oh, well" (Interview 15, Fall 2017). Multiple interviewees reported talking to other residents in the housing development about how much they all enjoyed the garden (Interview 2, 5, 6, 10, Fall 2015; Interview 19, Fall 2017). Compared to feelings of discomfort or shame they might have felt in utilizing food pantries, these seniors emphasized their enjoyment of the garden and how happy they were to receive deliveries. The lack of stress or negative feelings related to the OCG program points out that seniors may feel differently about utilizing a community giving garden program instead of other forms of assistance programs. Other private food assistance programs were met with dislike of the food quality or disapproval of the retail conditions. Unlike the issues raised in Feeding America's national review of public food assistance, seniors did not mention problems associated with public food assistance program eligibility, delays in service, or complicated hoops to jump though (O'Brien et al., 1999). Overcoming these obstacles could be a result of these seniors' resident service coordinator, who facilitated food access opportunities, but the OCG also functions without the barriers to food access that public programs can sometimes present, including trouble with the application, eligibility requirements, and the transportation that is often necessary to go purchase the food. The OCG program presents a strategy that eliminates any barriers to eligibility or paperwork, instead recruiting seniors and offering seniors the option to join the program without requiring an application or qualification status. Despite intermittent hesitancy and dislike for some assistance programs, such as food pantries, the seniors who were interviewed were open about their experiences with initiatives like the OCG and Parker Dining Room, suggesting that these types of programs did not incite negative feelings associated with accepting help.

Although results from our interviews indicated that the OCG program provided low-income seniors with safe access to much-needed food, there was no significant difference in the level of food security between seniors who participated in garden deliveries and those who did not. Both participants and nonparticipants displayed characterization of all four levels of food security and were represented similarly at each level. In fact, no distinct differences were observed between the level of indicated food security and senior participation in any of these programs or the number of programs they were participating in; seniors of all groups had been struggling, at some point, to maintain a level of high food security. While the OCG was not attributed with completely bringing seniors out of marginal, low, or very low levels of food security, it still functioned to provide critical access to food to some of the residents. Studies 
show that seniors who receive home-delivered meals over an extended period of time also report having higher overall rates of food security (Dean et al., 2011). Although they may not be able to fully relieve food insecurity for seniors, the muchneeded deliveries function as a consistent source of food that plays a role in how seniors define food access.

From this work we can conclude that food access rooted in community involvement and alternative food systems can be one of the tools that influences seniors' food security. The OCG program functions with a constellation of other programs to provide increased food access to many seniors in need of the garden's food deliveries. Despite having access to multiple food assistance programs, many seniors still fail to maintain a high level of food security because they are reliant on the amount of food received from these food sources. Their choices in food access are often restricted by perceived stigmas that deem the source of food assistance as a socially unacceptable way of achieving security.

Due to seniors' difficulty in understanding the definitions of food insecurity, as identified by the federal government, self-reporting is often inaccurate. Many seniors did not define themselves as food insecure, yet acknowledged relying on programs, such as the OCG, to improve their food access. Our work suggests that the OCG meets crucial needs by providing access to fresh, nutritional produce, and that Orono seniors perceived food assistance from the garden to carry far less stigma than other assistance programs.

Why was OCG successful? Facilitated recruitment, home delivery, and the lack of eligibility barriers were key factors that likely contributed to the higher participation rates in food assistance programs demonstrated by seniors in our study, when compared to barriers noted for senior participation rates across the nation (Daponte, 2000; Martin et al., 2003). Pudup (2008) found that community gardens are typically inclusive and will serve all community members, pointing to how similar donation-model gardens can be managed and omit the subjective notions that food assistance often bears. In this sense, especially if given adequate support, community gardens may serve a larger purpose to provide more effective and better utilized solutions to relieve food insecurity. Rather than thinking about community gardens solely as spaces of civic engagement and social centers, our responses indicated that community gardens function as a food assistance program and provide increased food access (Carney et al., 2012; Committee on National Statistics et al., 2013; Furness \& Gallaher, 2018).

\section{Conclusions}

Social change includes creating equitable access to opportunities and public systems that enable individuals to do more than just survive, and calls attention to issues of food justice. This work centered on the acceptance by low-income seniors of engaging in a community giving garden project. Consistent with the literature, our findings indicate there are many hurdles to achieving food security, and we acknowledge there are a variety of factors contributing to participation in different assistance programs and the hindering role that stigma plays in this particular demographic (as also demonstrated in the literature). We found that the OCG did not have barriers that would inhibit participation, unlike other food assistance programs mentioned in the literature, and senior households chose not to participate due to personal choice and perhaps local management of other programs. The benefits of a private food-donation program, such as the OCG, can be crucial to those in need. This study also found that these seniors participate in food assistance programs and typically in a combination of private and public food assistance programs at a much higher rate than observed nationally, a result that requires further inquiry to better understand. A key finding in this study is the lack of stigma associated with food assistance in the form of a community giving garden program. We suggest that public assistance programs must continue to provide consistent support to seniors alongside private options, such as community gardens, to maintain a commitment to equitable food access and as a means to help seniors alleviate food stress.

Creating food equity involves a comprehensive approach toward our complex food systems. Our work does not look to solve long-term problems of 
systemic disparity in food access, but instead supports the prospects of community gardens as one potential solution to a short-term problem to help alleviate pressure. Linking sustainable food production and the development of fair and accessible programs will support food sovereignty for all and help reduce the many inequities within our food systems (Vitiello et al., 2015). This community giving garden suggests an avenue that increases food security and simultaneously diminishes stigmatized views associated with food assistance programs.

We found these seniors to commonly misrepresent their level of food security and rely on a complex system of assistance, suggesting the true extent of their hardship to be worse and unclear. Like many other food assistance programs, the constellation of programs seen in Orono is uncoordinated in its efforts to address senior food security. These programs are also vulnerable, often run by volunteers, supported with limited resources, and as such, are at risk of termination. Although lacking a systematic approach, these programs function as a safety net to support the nutrition of many seniors in Orono. The loss of a single program could place some secure seniors in positions of instability or increased food insecurity. These results can be viewed as a reflection of the failure of structural opportunities within a community to facilitate access to food (Dean et al., 2011). Community giving gardens should be favored as an emerging solution to this problem in providing destigmatized food access and building local food economies. We must achieve a more compre- hensive understanding of food access in our nation, information that will equip us with the knowledge of how to navigate building food equity and resilient, inclusive food systems.

Encouraging further examination of the perception of food access and food planning behaviors may have broader impacts in addressing systemic change. Studies conducted by Daponte (2000) and Wu and Eamon (2007) found a negative correlation between age and the likelihood to use food assistance, but we have yet to understand the many factors that prevent seniors from using available food resources. In designing effective programs to combat food insecurity, seniors' perception of food assistance should be strongly considered. Future research should explore the widespread scale of food-access issues for rural low-income populations, determine how often and to what extent community giving gardens are playing a role in rural food systems planning, and explore the potential role of community garden programs in creating resilient community resources. Prospective longitudinal case studies should be built to better understand how older Americans hide their hunger and the ways we can create equitable access to food.

\section{Acknowledgments}

Thank you to the anonymous reviewers for their helpful comments. We would like to thank the individuals who volunteered to be interviewed and all the volunteers involved in the Oromo community garden over the past 17 years, without whom this work would not have been possible.

\section{References}

Bangor Daily News Staff. (2011, March 10). Maine Senior FarmShare enrollment begins. Bangor Daily News. https://bangordailynews.com/2011/03/10/news/maine-senior-farmshare-enrollment-begins/

Burnett, P., Matlins, A., \& University of Maine Center on Aging. (2006). Civic engagement. Maine Center on Aging and Research Evaluation. https://digitalcommons.library.umaine.edu/moca research/34

Carney, P. A., Hamada, J. L., Rdesinski, R., Sprager, L., Nichols, K. R., Liu, B. Y., Pelayo, J., Sanchez, M. A., \& Shannon, J. (2012). Impact of a community gardening project on vegetable intake, food security and family relationships: A community-based participatory research study. Journal of Community Health, 37(4), 874-881. https://doi.org/10.1007/s10900-011-9522-z

Chicago Community Gardeners Association. (n.d.). Share the harvest: Guidelines for donating produce from community gardens. Retrieved June 29, 2020 from http://chicagocommunitygardens.org/resources menu/share-the-harvest/ 
Coleman-Jensen, A., Rabbitt, M. P., Gregory, C. A., \& Singh, A. (2019). Household food security in the United States in 2018 (Report No. ERR-270). U.S. Department of Agriculture, Economic Research Service. https://www.ers.usda.gov/publications/pub-details/?pubid=94848

Committee on National Statistics, Division of Behavioral and Social Sciences and Education, Food and Nutrition Board, National Research Council, \& Institute of Medicine. (2013). Community responses to food insecurity and hunger. In Research opportunities concerning the causes and consequences of child food insecurity and hunger: $A$ workshop summary. National Academies Press. https://doi.org/10.17226/18504

Cotterell, N., Buffel, T., \& Phillipson, C. (2018). Preventing social isolation in older people. Maturitas, 113, 80-84. https://doi.org/10.1016/j.maturitas.2018.04.014

Dabrowska, A. (March 8, 2017). Malnutrition in older adults. Memorandum Prepared for the Congressional Research Service.

D’Abundo, M. L., \& Carden, A. M. (2008). "Growing wellness": The possibility of promoting collective wellness through community garden education programs. Community Development, 39(4), 83-94. https://doi.org/10.1080/15575330809489660

Damon, E. (2017). A comprehensive overview of senior food insecurity [Unpublished manuscript]. Department of Plant, Soil, and Environmental Sciences, University of Maine.

Daponte, B. O. (2000). Private versus public relief: Use of food pantries versus food stamps among poor households. Journal of Nutrition Education, 32(2), 72-83. https://doi.org/10.1016/S0022-3182(00)70523-1

Dean, W. R., Sharkey, J. R., \& Johnson, C. M. (2011). Food insecurity is associated with social capital, perceived personal disparity, and partnership status among older and senior adults in a largely rural area of central Texas. Journal of Nutrition in Gerontology and Geriatrics, 30(2), 169-186. https://doi.org/10.1080/21551197.2011.567955

Dooley, O. (2017). Older Mainers, empty plates: Research on senior food insecurity in Maine. Good Shepherd Food Bank. https://www.gsfb.org/wp-content/uploads/2013/10/Senior-Hunger-Report.pdf

Drake, L., \& Lawson, L. J. (2015). Results of a US and Canada community garden survey: Shared challenges in garden management amid diverse geographical and organizational contexts. Agriculture and Human Values, 32, $241-254$. https://doi.org/10.1007/s10460-014-9558-7

Dwiartama, A., \& Piatti, C. (2016). Assembling local, assembling food security. Agriculture and Human Values, 33, 153 164. https://doi.org/10.1007/s10460-015-9624-9

Eastern Agency Area on Aging. (2018, May 4). Senior food programs—Social dining sites. Retrieved June 30, 2020 , from https://www.eaaa.org/social-dining/

Feeding America. (2020a). Map the meal gap 2020: A report on county and congressional district food insecurity and county food cost in the United States in 2018. https://www.feedingamerica.org/sites/default/files/202006/Map $\% 20$ the $\% 20 \mathrm{Meal} \% 20 \mathrm{Gap} \% 202020 \% 20$ Combined $\% 20$ Modules.pdf

Feeding America. (2020b). The impact of the coronavirus on food insecurity. https://www.feedingamerica.org/research/coronavirus-hunger-research

Feulner, N. (2015, March 8 / Updated 2015, April 17). Garden plots in Maine cultivate sense of community. Bangor Daily News. https://bangordailynews.com/2015/03/08/news/garden-plots-in-maine-cultivate-sense-of-community/

Frongillo, E. A., \& Horan, C. M. (2004). Hunger and aging. Generations: Journal of the American Society on Aging, 28(3), 2833. https://www.jstor.org/stable/26555320

Frongillo, E. A., \& Warren, A. M. (2018). An evaluation report: Senior food-assistance, related programming, and seniors' experiences across the Feeding America Network. Feeding America. https://www.feedingamerica.org/sites/default/files/research/senior-hunger-research/senior-hunger-evaluation.pdf

Furness, W. W., \& Gallaher, C. M. (2018). Food access, food security and community gardens in Rockford, IL. Local Environment, 23(4), 414-430. https://doi.org/10.1080/13549839.2018.1426561

Gabor, V., Williams, S. S., Bellamy, H., Hardison, B. L., \& Dagata, E. (2002). Seniors' views of the food stamp program and ways to improve participation - Focus group findings in W ashington State: Final report (Report No. EFAN-02-012). U.S.

Department of Agriculture, Economic Research Service. https://www.ers.usda.gov/publications/pub-details/?pubid=43163 
Gerster-Bentaya, M. (2013). Nutrition-sensitive urban agriculture. Food Security, 5, 723-737. https://doi.org/10.1007/s12571-013-0295-3

Good Shepherd Food Bank \& Preble Street. (2017). Hunger pains: Widespread food insecurity threatens Maine's future. https://www.gsfb.org/wp-content/uploads/2018/01/Food-Pantry-Report-2-6-171.pdf

Graham, G. (2014, January 5). Swallowing their pride to avoid going hungry. Portland Press Herald / Maine Sunday Telegram. https://specialprojects.pressherald.com/aging/swallowing-their-pride-to-avoid-going-hungry

Gualtieri, M. C., \& Donley, A. M. (2016). Senior hunger: The importance of quality assessment tools in determining need. Journal of Applied Social Science, 10(1), 8-21. https://doi.org/10.1177/1936724414561258

Haggerty, M., Jemison Jr., J. M., Mullis, S., \& Ladenheim, M. (2016). Community gardens and seniors: An effectual relationship? [Conference session]. Agriculture, Food, and Human Values Conference in Toronto, Ontario, CA.

Irazábal, C., \& Punja, A. (2009). Cultivating just planning and legal institutions: A critical assessment of the South Central Farm struggle in Los Angeles. Journal of Urban Affairs, 31(1), 1-23. https://doi.org/10.1111/j.1467-9906.2008.00426.x

Kurtz, H. (2001). Differentiating multiple meanings of garden and community. Urban Geography, 22(7), 656-670. https://doi.org/10.2747/0272-3638.22.7.656

Macias, T. (2008). Working toward a just, equitable, and local food system: The social impact of community-based agriculture. Social Science Quarterly, 89(5), 1086-1101. https://doi.org/10.1111/j.1540-6237.2008.00566.x

Maine Department of Agriculture, Conservation and Forestry. (n.d.). Real Maine: Maine Senior FarmShare Program. Retrieved July 2, 2020, from https://www.getrealmaine.com/index.cfm/fuseaction/home.showpage/pageID/77/index.htm

Martin, K. S., Cook, J. T., Rogers, B. L., \& Joseph, H. M. (2003). Public versus private food assistance: Barriers to participation differ by age and ethnicity. Journal of Nutrition Education \& Bebavior, 35(5), 249-254. https://doi.org/10.1016/S1499-4046(06)60055-9

Mather, M., \& Kilduff, L. (2020). The U.S. population is growing older, and the gender gap in life expectancy is narrowing [Article excerpt]. Population Reference Bureau. https://www.prb.org/resources/u-s-population-is-growing-older/

Meals on Wheels America. (2017). Hunger in older adults: Challenges and opportunities for the Aging Services Network. Meals on Wheels America. https://www.mealsonwheelsamerica.org/learn-more/research/hunger-in-older-adults

Meals on Wheels America. (2019). The escalating problem of senior hunger \& isolation [Factsheet].

Moffitt, R. (1983). An economic model of welfare stigma. The American Economic Review, 73(5), 1023-1035. https://www.jstor.org/stable/1814669

Mullis, S. (2016). Alleviating social isolation and food insecurity through community gardening: How the Orono Community Garden impacts seniors.https://digitalcommons.library.umaine.edu/honors/403/

National Council on Aging. (2019, August). Senior hunger and SNAP fact sheet. Retrieved June 29, 2020, from https://www.ncoa.org/article/get-the-facts-on-snap-and-senior-hunger

O’Brien, D., Prendergast, K., Thompson, E., Fruchter, M., \& Aldeen, H. T. (1999). The red tape divide: State-by-state review of food stamp applications. America's Second Harvest. https://www.issuelab.org/resources/95/95.pdf

Obach, B. K., \& Tobin, K. (2014). Civic agriculture and community engagement. Agriculture and Human Values, 31, 307322. https://doi.org/10.1007/s10460-013-9477-z

Okvat, H. A., \& Zautra, A. J. (2011). Community gardening: A parsimonious path to individual, community, and environmental resilience. American Journal of Community Psychology, 47(3-4), 374-387. https://doi.org/10.1007/s10464-010-9404-z

Pingree, C. (2012). The local food movement: From Maine to Washington, D.C. Journal of Food Law \& Policy, 8(1), 203-212.

Pudup, M. B. (2008). It takes a garden: Cultivating citizen-subjects in organized garden projects. Geoforum, 39(3), 1228-1240. https://doi.org/10.1016/i.geoforum.2007.06.012

Quandt, S. A., Arcury, T. A., McDonald, J., Bell, R. A., \& Vitolins, M. Z. (2001). Meaning and management of food security among rural elders. Journal of Applied Gerontology, 20(3), 356-376. https://doi.org/10.1177/073346480102000307 
Ratcliffe, C., \& McKernan, S.-M. (2010). How much does SNAP reduce food insecurity? (Contractor and Cooperator Report No. 60). The Urban Institute. https://doi.org/10.22004/ag.econ.292080

Rinehart, S. W., Folliard, J. N., \& Raimondi, M. P. (2016). Building a connection between senior hunger and health outcomes. Journal of the Academy of Nutrition and Dietetics, 116(5), 759-760. https://doi.org/10.1016/i.jand.2016.02.009

Saldaña, J. (2013). The coding manual for qualitative researchers ( $3^{\text {rd }} \mathrm{Ed}$.). SAGE.

Schaefer, A., \& Mattingly, M. J. (2016). A portrait of wellbeing: The status of seniors in Maine. John T. Gorman Foundation. https://www.jtgfoundation.org/wp-content/uploads/2018/09/Data Book Maine Seniors Count JAN-2216 FINAL-1.pdf

Sutphen, E. (2018). The Denison Pequotsepos Nature Center Giving Garden at Coogan Farm: A practitioner report on community gardens for health and regional food security. International Development, Community and Environment (IDCE). https://commons.clarku.edu/idce masters papers/190

Teig, E., Amulya, J., Bardwell, L., Buchenau, M., Marshall, J. A., \& Litt, J. S. (2009). Collective efficacy in Denver, Colorado: Strengthening neighborhoods and health through community gardens. Health \& Place, 15(4), $1115-1122$. https://doi.org/10.1016/j.healthplace.2009.06.003

Twiss, J., Dickinson, J., Duma, S., Kleinman, T., Paulsen, H., \& Rilveria, L. (2003). Community gardens: Lessons learned from California Healthy Cities and Communities. American Journal of Public Health, 93(9), 1435-1438. https://doi.org/10.2105/AJPH.93.9.1435

U.S. Census Bureau. (2010). 2010 Census urban and rural classification and urban area criteria. https://www.census.gov/programs-surveys/geography/guidance/geo-areas/urban-rural/2010-urban-rural.html

U.S. Department of Agriculture. (2019). Commodity Supplemental Food Program [Factsheet]. https://www.fns.usda.gov/csfp/csfp-fact-sheet

U.S. Department of Agriculture, Economic Research Service. (2019). Measurement of food security.

Vespa, J., Medina, L., \& Armstrong, D. M. (2020). Demographic turning points for the United States: Population projections for 2020 to 2060 (Current Population Reports, P25-1144). U.S. Census Bureau. https://heartlandcua.org/common/Uploaded\%20files/DEI/Census projections.pdf

Vitiello, D., Grisso, J. A., Whiteside, K. L., \& Fischman, R. (2015). From commodity surplus to food justice: Food banks and local agriculture in the United States. Agriculture and Human Values, 32, 419-430. https://doi.org/10.1007/s10460-014-9563-x

Walter, P. (2013). Theorising community gardens as pedagogical sites in the food movement. Environmental Education Research, 19(4), 521-539. https://doi.org/10.1080/13504622.2012.709824

Wolfe, W. S., Frongillo, E. A., \& Valois, P. (2003). Understanding the experience of food insecurity by elders suggests ways to improve its measurement. The Journal of Nutrition, 133(9), 2762-2769. https://doi.org/10.1093/jn/133.9.2762

Wolfe, W. S., Olson, C. M., Kendall, A., \& Frongillo Jr., E. A. (1996). Understanding food insecurity in the elderly: A conceptual framework. Journal of Nutrition Education, 28(2), 92-100. https://doi.org/10.1016/S0022-3182(96)70034-1

Wu, C.-F., \& Eamon, M. K. (2007). Public and private sources of assistance for low-income households. Journal of Sociology and Social Welfare, 34(4) 121-149. https://scholarworks.wmich.edu/jssw/vol34/iss4/7

Zepeda, L. (2017). Hiding hunger: Food insecurity in middle America. Agriculture and Human Values, 35(1), $243-254$. https://doi.org/10.1007/s10460-017-9818-4

Ziliak, J. P., \& Gunderson, C. (2020). The state of senior bunger in America 2018: An annual report. Feeding America. https://www.feedingamerica.org/sites/default/files/2020-05/2020The $\% 20$ State $\% 20$ of $\% 20$ Senior $\% 20$ Hunger $\% 20$ in $\% 202018$.pdf 